\begin{tabular}{|c|c|c|c|c|c|c|}
\hline \multirow{4}{*}{ Impact Factor: } & ISRA (India) & $=4.971$ & SIS (USA) & $=0.912$ & ICV (Poland) & $=6.630$ \\
\hline & ISI (Dubai, UAE & $=0.829$ & РИНЦ (Russia) & $=0.126$ & PIF (India) & $=1.940$ \\
\hline & GIF (Australia) & $=0.564$ & ESJI (KZ) & $=8.716$ & IBI (India) & $=4.260$ \\
\hline & JIF & $=1.500$ & SJIF (Morocco) & $=5.667$ & OAJI (USA) & $=0.350$ \\
\hline
\end{tabular}

\section{SOI: $1.1 /$ TAS $\quad$ DOI: $10.15863 /$ TAS \\ International Scientific Journal Theoretical \& Applied Science}

p-ISSN: 2308-4944 (print) e-ISSN: 2409-0085 (online)

Year: $2020 \quad$ Issue: 03 Volume: 83

Published: $30.03 .2020 \quad$ http://T-Science.org
QR - Issue

QR - Article
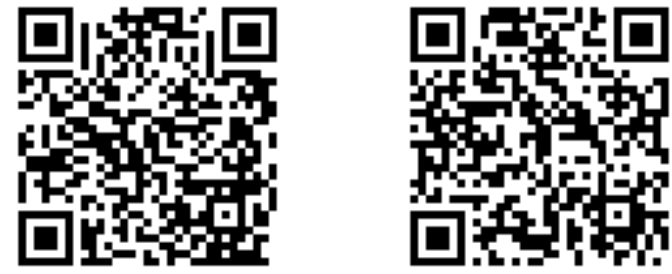

Rustam Mansurovich Sadikov

Tashkent State Pedagogical University named after Nizami

Teacher of the "Distance education" department,

Uzbekistan

\title{
TEACHER'S WORK ON ARTWORK AT READING LESSONS AT PRIMARE SCHOOL
}

Abstract: This article reveals the stages of artwork in reading lessons used in primary school. The content of the work is described at each stage of reading a work of art in primary school.

Key words: Synthesis, analysis, perception, illustration, verbal, graphic.

Language: English

Citation: Sadikov, R. M. (2020). Teacher's work on artwork at reading lessons at primare school. ISJ Theoretical \& Applied Science, 03 (83), 342-345.

Soi: http://s-o-i.org/1.1/TAS-03-83-63 Doi: crossef https://dx.doi.org/10.15863/TAS.2020.03.83.63

Scopus ASCC: 3304.

\section{Introduction}

Big changes are happening in Uzbekistan in the education sphere. President of Uzbekistan Sh. Mirziyoyev began full-scale globalization in all spheres of the life of people. Of particular importance is the training and education of the younger generation. A great joy for teachers is the fact that students are entering the world arena. For the relatively young Republic, the indicative results of participation in various competitions in subjects are especially pleasing.

In work on fiction, the teacher relies on the data of modern psychology, literary criticism and wide pedagogical experience. The peculiarity of working with artwork in elementary grades is its practical orientation, it is determined by the age characteristics of students. A work of art is a complex whole in which all its components are interconnected and interact with each other.

As a result of the above, work on a composition is divided into three main stages:

1) the first stage is the primary synthesis;

2) the second stage is analysis;

3) the third stage is secondary synthesis. [1]

The sequence of work with fiction is based on the laws of perception of fiction, and it begins with preparation for reading.

The teacher must create all conditions for a vivid, emotional perception of the artwork.
The tasks of the preparatory work are:

- expand students' perceptions of the phenomens, events depicted in the artwork;

- introduce the life of a writer;

- prepare for the emotional perception of the work;

- reveal to children the lexical meaning of unfamiliar words. [2]

Various didactic forms of preparatory work are possible, e.g: a teacher's story, a demonstration of reproductions of paintings by artists, a film demonstration, listening to a tape recording, conversation, and a tour. The story of the teacher. Interest in a artwork will increase significantly if you introduce students to a writer - author of a work, his life, creativity. Demonstration of films.

Filmstrips and films will help students consolidate and supplement information, systematize the representations they have. Cognitive material of films promotes conscious reading and a vivid emotional perception of the content. Excursion. During the excursions, student's knowledge about natural phenomena deepens and expands.

It is also an opportunity to develop the ability of children to observe, describe natural phenomena, the ability to cultivate their love of nature and respect for it. 


\begin{tabular}{|c|c|c|c|c|c|c|}
\hline \multirow{4}{*}{ Impact Factor: } & ISRA (India) & $=4.971$ & SIS (USA) & $=0.912$ & ICV (Poland) & $=6.630$ \\
\hline & ISI (Dubai, UAE & $=0.829$ & РИНЦ (Russia) & $=0.126$ & PIF (India) & $=1.940$ \\
\hline & GIF (Australia) & $=0.564$ & ESJI (KZ) & $=8.716$ & IBI (India) & $=4.260$ \\
\hline & JIF & $=1.500$ & SJIF (Morocco) & $=5.667$ & OAJI (USA) & $=0.350$ \\
\hline
\end{tabular}

The first stage of work on the text involves introducing students to the specific content of the text, clarifying the emotional impact of the artwork.

At the second stage, the text is analyzed in order to establish causal relationships in the development of the plot, to clarify the motives of behavior actors and their main features, the disclosure of the composition of a work, the identification of pictorial means in unity with the disclosure of a specific content and assessment of the motives of the behavior of the heroes. The content of the work at the third stage is: a synthesis of the essential features of the actors, a comparison heroes and their assessment, clarification of the ideological orientation of the work, assessment of the work as a source of knowledge of the surrounding reality and how works of art. After such work, you can conduct creative work - composition, presentation. The connection with the life experience of students carried out throughout the work on the work. But as the analysis deepens, enrichment of schoolchildren with the thoughts and experience of the author, connection with Students' life experience is changing qualitatively. On the one hand, the author acts on the student with a logical and emotionallyshaped side works. On the other hand, creatively reworking the work, the student forms his view of things and phenomena that are not always identical to the author's. The text is read by a teacher or a pretrained student. Then a conversation is held, which aims to find out what impression the work made on students, to interest children in the analysis of the text and create conditions for active work in the lesson. The teacher can formulate the questions as follows: What moment did you find the story most interesting? Why? What part of the story do you remember most? What picture do you most vividly imagine listening to the story? Which of the heroes did you especially like? When was it especially joyful (sad) for you? Regulation on the relationship between skill formation reading and the ability to work with text is one of the most important for the teacher and determines his approach to the analysis of the work. Second possible methodological the provision is an interconnected consideration of the content and visual means of the work. The third starting position is integrated implementation of educational and educational tasks in the process of working on a work. The main directions of text analysis: clarification specific content, composition of the work, motives of the actors' behavior and their characteristic features, ideological orientation of the work. [4]

The types of work with text in the analysis process can be next:

1. Selective reading - reading part of the text in accordance with the task. Selective reading is used in conjunction with other types of work - with compiling a characterization of the hero, with the disclosure of the idea of the artwork. This is necessary for the development of the creative imagination of children, their speech and memory.

2. Answers to questions in your own words - the most common type of work with text. This type of work develops the ability to reason about what has been read.

3. The questioning by the students themselves is also an effective type of work with text. Asking questions in the text can be homework, which provides students with activity when checking homework in the classroom.

4. For the development of creative imagination of students is this type of work, as an illustration of the text used in 2 versions:

a) verbal;

Verbal drawing is a peculiar and rather important type of work, it is considered one of the effective means of speech development of students. Graphic drawing can most often be done at home. On the illustrations of students in the lesson, selective reading is carried out, this allows you to consolidate the connection words and image.

5. The necessary types of work on the text include retelling. Types of retelling: detailed, concise, selective, creative.

6. Drawing up a work plan is carried out with the aim of a more conscious and deep understanding of the content of the artwork. Skills training the plan is built taking into account the gradual increase in difficulties and is carried out in a certain system, starting from the 2 nd grade. Clarification of an idea is the core analysis of an artwork. The disclosure of ideas combines all the components of analysis. Based on the idea, the teacher builds a system of questions and tasks. Although in the primary grades students are not specifically acquainted with the theme and idea of the work, these terms are not introduced, but what the writer tells about students can find out by analyzing the text and what is their main idea. The idea in a work of art is revealed through an image or a system of images, through the actions of heroes, their relationships. Therefore, it is necessary to find out the motives of the actors' behavior, their connection with the facts and events of artwork. Through facts and events, attitude to actors the author shows his ideological position, reveals his worldview. In the process of work on the work, during the analysis, an estimated the judgment of students, their worldview. Therefore, the analysis should take place as an informal conversation in which the author and his characters are present. More often Summarizing the specific content of the story, students come to understand the idea. [5]

If in the story the idea is clearly formulated by the author in one or two sentences, it is revealed in two ways:

a) from specific content to a generalized conclusion, 


\begin{tabular}{|c|c|c|c|c|c|c|}
\hline \multirow{4}{*}{ Impact Factor: } & ISRA (India) & $=4.971$ & SIS (USA) & $=0.912$ & ICV (Poland) & $=6.630$ \\
\hline & ISI (Dubai, UAE & $=0.829$ & РИНЦ (Russia & $=0.126$ & PIF (India) & $=1.940$ \\
\hline & GIF (Australia) & $=0.564$ & ESJI (KZ) & $=8.716$ & IBI (India) & $=4.260$ \\
\hline & JIF & $=1.500$ & SJIF (Morocec & $=5.667$ & OAJI (USA) & $=0.350$ \\
\hline
\end{tabular}

b) from the conclusion to specific events. After the first perception of the content of the text, students can be offered find the words (sentences) in which the main idea is expressed, and say what events the thought is in. This task allows you to create a search situation, Interested in re-reading the story. Correct emotional perception of the story is one of the most important conditions for understanding the idea artwork. Reflections on why the composition is so named also leads to an understanding of the idea, its theme.

The material in reading books is arranged taking into account the ideological and thematic principle. The teacher develops a system of lessons, taking into account the general ideological and thematic basis works combined in one section. The teacher must know exactly what knowledge students should enrich, what personal qualities he will cultivate in the process of reading this cycle of works.[6]

It is necessary to strive for a holistic analysis of the composition: work on the disclosure of the idea takes place simultaneously with work on the features actors, visual means of the text, over the skill of informed and expressive reading. In primary school, the term actor is used, not "image." The task of teaching work with text is to develop in schoolchildren by the end of the 4th grade the ability to select material about the characters, (to be able) to evaluate their actions, express their attitude to them, make a story about the characters.

In preparing for reading lessons, the teacher should proceed from the following provisions:

1. In the image - character, the author summarizes his life observations on human characters and at the same time, the image is concrete. Therefore students in the analysis process should perceive the actor as a representative of a certain social group of people, a certain era and at the same time as a specific living person with specific characteristics.

2 . In the process of revealing the characteristic features of the hero of the artwork, stand out leading, main features. More often it is this main characteristic that explains the motives of the hero of the artwork, allows you to understand the image as a whole. But not less to consider this feature is necessary in connection with other features, to teach children to see the hero in all the complexity and dialectical inconsistency of the features.
3. Understanding by students of the image - the character helps to clarify the author's attitude to a particular hero. If the author in the works expresses his attitude to the actors in value judgments, then students must independently find these words and prove with examples from the text, why the author says so, to cite the facts in support of this assessment.

4. An important condition for the effectiveness of work on the image of art the work is empathy with the reader, his sympathy or antipathy to the image the character. Image analysis - the character should include as obligatory of its component, clarification of students' own attitude to the actors of the artwork. Stage of work on the image - character determined taking into account the psychological foundations of the process of perception of a work of art by younger students. At the 1st stage - emotional, often unmotivated perception of the image by students, specification of their initial holistic perception at the 2nd stage, and generalized motivational-evaluative judgment, which students come to the 3rd stage.

Stage I - the initial perception of the text, a holistic impression of the characters in the emotional plan.

Stage II - careful work with the text, the formation of students' ability to select material about the characters. At the final stage III, students generalize the selected specific material, make up a story about the hero, the main questions on which Students are prepared as follows:

1) Who is he?,

2) appearance

3) attitude to people, to the assigned case,

4) your attitude to it. Summarizing the material about the characters, students are brought to the idea of the work. From class to class, work on the main idea of the work and its actors complicated. [7]

Grade II - the ability to highlight with the help of a teacher the main idea of what is read. The ability to find words and expressions that characterize the events of the characters.

Grade III - the ability to highlight the main content of the part and the story as a whole, to evaluate the actions of the heroes.

Grade IV - the ability to select material for speaking about the characters, evaluate their actions, express their attitude to them, make a story ab.

The independence of students in working with text is increasing out the hero.

\section{References:}

1. Arkhipova, E.V. (1995). The development of speech: a textbook for primary school teachers. Moscow.
2. Baranov, M.T., Ladyzhenskaya, T.A., \& Lviv, M.R. (1990). Methods of teaching the Russian language. Moscow. 


\begin{tabular}{|c|c|c|c|c|c|c|}
\hline \multirow{4}{*}{ Impact Factor: } & ISRA (India) & $=4.971$ & SIS (USA) & $=0.912$ & ICV (Poland) & $=6.630$ \\
\hline & ISI (Dubai, UAE & $=0.829$ & РИНЦ (Russia & $=0.126$ & PIF (India) & $=1.940$ \\
\hline & GIF (Australia) & $=0.564$ & ESJI (KZ) & $=8.716$ & IBI (India) & $=4.260$ \\
\hline & JIF & $=1.500$ & SJIF (Morocec & $=5.667$ & OAJI (USA) & $=0.350$ \\
\hline
\end{tabular}

3. Kozhukhovskaya, V.M., Isangulova, R.F., \& Nesgovorova, V.M. (2005). Journey into the world of words. A book for reading in the 2nd grade. Tashkent.

4. Lvov, M.R., Ramzaeva, T.G., \& Svetlovskaya, N.N. (1987). Methods of teaching Russian in elementary grades. Moscow.

5. Panov, B.T. (1980). Extracurricular work in the Russian language. A manual for teachers. Moscow.

6. Sadikova, A.V. (n.d.). Useing Information Technology in Verifying Students' Knowledge, Eastern European Scientific Journal, pp.129133. (ISSN 2199-7977) DOI 10.12851/EESJ201805.

7. Tokhtakhodjaeva, M.Kh., Weitzman, N.M., \& Belova, V.A. (1997). Literacy and speech development program for students in grade 1, Tashkent. 